To be published in the Proceedings from the International Workshop on Mechanisms in Fibre Carcinogenesis, Albuquerque, NM, Cctober 22-25, 1990.

\title{
RADIATION-INDUCED MESOTHELIOMAS IN RATS
}

F. F. Hahn, P. J. Haley, A. F. Hubbs, M. D. Hoover, and

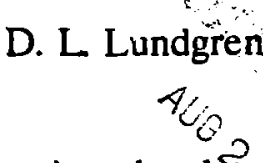

Mesotheliomas have been reported in rats that inhaled plutonium, but have not been extensively studied (Dagle and Sanders, 1984). Rats injected intraperitoneally oth $100 \mathrm{kBq}$ of ${ }^{239} \mathrm{PuO}_{2}$ developed mesotheliomas around focal, high concentrations of plutonium "hot spots" localized in the omentum (Sanders and Jackson, 1972). In this study, $27 \%$ of the rats developed peritoneal mesotheliomas (epithelial in morphology) and $38 \%$ developed sarcomas (sarcomatous mesotheliomas). The tumor incidence was dose dependent and a greater dose was required for the induction of epithelial mesotheliomas than for the sarcomas. When 3,4-benzo-a-pyrene or chrysotile asbestos fibers were injected with the ${ }^{239} \mathrm{PuO}_{2}$, the resultant tumor incidence was additive (Sanders, 1973). The morphogenesis of the mesotheliomas from intraperitoneally injected ${ }^{239} \mathrm{PuO}_{2}$ and chrysotile asbestos was similar.

Radiation-associated mesotheliomas have also been reported in human patients several years after therapeutic external radiation for Wilms tumor, seminoma, thyroid ablation, teratocarcinoma, infiltrating breast carcinoma, or Hodgkin's disease (Peterson et al., 1984). Thorium dioxide, a radioactive, radiographic contrast media, has also been implicated in mesothelioma induction. Two cases have been described in which contamination of the peritoneal or pleural cavity was associated with mesothelioma appearing 25 and 36 years later.

To investigate a possible role for inhaled radionuclides in the induction of mesotheliomas, we reviewed four life-span studies conducted at ITRI in which rats had inhaled radioactive materials. A total of 3076 F344 rats were exposed by inhalation to aerosols of ${ }^{239} \mathrm{PuO}_{2}$, mixed uranium-plutonium oxide, or ${ }^{144} \mathrm{CeO}_{2}$. Results showed that a low incidence of pleural mesotheliomas was induced by either alpha- or beta-emitting radionuclides deposited and retained in the lung.

The first study reviewed involved 716 rats exposed once or repeatedly ( 7 times over one year) to monodisperse aerosols of ${ }^{239} \mathrm{PuO}_{2}$ (Lundgren et al, 1990). The aerosols were about $1 \mu \mathrm{m}$ AMAD with a geometric standard deviation $\left(\sigma_{\mathcal{g}}\right)$ of about 1.2. The initial lung burdens (ILB's) ranged from 0.11-1.5 kBq. Most of the plutonium 
particles were retained in the lung with a half-time of about 30 days (Fig. 1a). Nine to 11 percent of the initial lung burden was retained with a half-time of 790-1050 days.

The second study reviewed involved 461 rats exposed to aerosols of plutonium dioxide $\left(69 \%{ }^{239 / 240} \mathrm{Pu}, 17 \%{ }^{238} \mathrm{Pu}, 15 \%{ }^{241} \mathrm{Am}\right.$ ), or uranium-plutonium oxides (43\% ${ }^{239 / 240} \mathrm{Pu}, 35 \%{ }^{238} \mathrm{Pu}, 22 \%{ }^{241} \mathrm{Am}$ ) obtained from glove boxes in a nuclear reactor fuel fabrication facility (Mewhinney et al., 1987). The aerosols were generated from dry powders and had an AMAD of about $3.5 \mu \mathrm{m}\left(\sigma_{\mathrm{g}}=1.4\right)$ for $\mathrm{PuO}_{2}$ and an AMAD of about $2.1 \mu \mathrm{m}\left(\mathrm{o}_{\mathrm{g}} 1.5\right)$ for the mixed uranium plutonium oxide. Most of the $\mathrm{PuO}_{2}$ was retained with a half-time of about 41 days (Fig. 1b). Two percent of the ILB of $\mathrm{PuO}_{2}$ was retained with an 810 day hali-time. Most of the uranium-plutonium oxide material was retained with a half-time of about 15 days. Four percent of the ILB was retained with a half-time of 1700 days.

The third study reviewed involved 329 rats exposed once or repeatedly $(7$ times over one year) to aerosols of ${ }^{144} \mathrm{CeO}_{2}$ (Lundgren et al., 1990). The aerosols had 0.9-1.4 $\mu \mathrm{m}$ AMAD $\left(\sigma_{\mathrm{g}} 1.4-2.0\right)$. The ILB's ranged from 13 to $40 \mathrm{kBq}$. For the rats exposed once, $82 \%$ of the cerium was retained in the lung with a half-time of 12 days and $18 \%$ with a half-time of 70 days (Fig. 1c). Repeated exposure prolonged the retention resulting in $48 \%$ being retained with a half-time of 15 days and $52 \%$ with a half-time of 100 days.

The fourth study reviewed involved 1570 rats exposed to relatively low doses of ${ }^{144} \mathrm{CeO}_{2}$ (Lundgren et al., 1990). The aerosols were 0.9-1.4 $\mu \mathrm{m}\left(\sigma_{\mathrm{g}} 1.4-2.0\right)$. The ILB's ranged from $13-160 \mathrm{kBq}$. Most of the cerium was retained with a half-time of 29 days (Fig. 1d). Nine percent was retained with a half-time of 160 days.

A number of features were similar in all four studies. In all the exposures, aerosol particles were basically spherical in shape and respirable in size (Fig. 2). No fibers were present in the aerosols. The rats were exposed briefly (10-40 min) per nasum, to the aerosols. Approximately equal numbers of male and female F344 rats, raised in the Institute colony, were used in each study. The rats were observed twice daily until they died or were euthanized. 
At death, each rat was necropsied and all major organ systems were examined. Routine paraffin-embedded, hematoxylin- and eosin-stained sections were obtained from the lung and from lesions in the thoracic cavity. Sections of other organs were taken as required for diagnosis of lung lesions.

Over the range of doses used in the four studies, only in the highest dose groups of two of the studies $\left({ }^{239} \mathrm{PuO}_{2}\right.$ single exposure and ${ }^{144} \mathrm{CeO}_{2}$ repeated exposure) was the life span significantly reduced. These life spans were $86 \%$ and $80 \%$ of their respective control groups. This long survival indicates that competing risks were not an important factor in the tumor incidence analysis.

The morphologic patterns of the 28 pleural mesotheliomas found in the 3076 rats exposed to radionuclides are noted in Table 1. Epithelial mesotheliomas with a papillary pattern were the most frequently seen (23/28 cases) (Fig. 3 ). Tumor tissue was found spread over much of the mesothelial surface of the lung and caused thickening of the mediastinum. Most of these tumors were considered either fatal or contributory to death, based on the extensive growth of the tumors. Two of these tumors occurred in rats that also had squamous cell carcinomas of the lung. Four of the mesotheliomas occurred in lungs where focal fibrosis was prominent. This association of mesotheliomas in rats with other lesions occurred in rats receiving the highest radiation doses ( $>17 \mathrm{~Gy}$ alpha or $>190$ Gy beta).

The sarcomatous mesotheliomas noted ( $2 / 28$ cases) were characterized by marked proliferation of spindle-shaped cells with large accumulations of mature collagen (Fig. 4). The tumors appeared to arise in the hilus of the lung, invade the mediastinum and heart, and spread along the pleural surface of the lung. Other primary lung tumors were noted in the rats with sarcomatous mesotheliomas.

The three mixed mesotheliomas had both papillary epithelial elements and sarcomatous elements (Fig. 5). Two of the three rats with mixed mesotheliomas also had other primary lung tumors.

In none of the mesotheliomas was anaplasia marked or the mitotic rate more than minimally increased. Tumors were considered malignant if they invaded normal tissue, implanted along pleural surfaces, and were fatal or contributed to death. 
The insidence of malignant mesotheliomas is shown in Figure 6. The incidence for the combined control animals ( 4 mesotheliomas $/ 1641$ control rats) was $0.24 \%$. The incidence ranged from 0.8 to $13.8 \%$ for rats that inhaled alpha-emitting radionuclides and from 2 to $5 \%$ for rats that inhaled beta-emitting radionuclides. The interrelationship of the incidence and dose to lung was tested with linear regression. For alpha-emitting radionuclides, the relationship was described by $\mathrm{Y}=(0.95) \mathrm{X}+0.029$ with a correlation coefficient of 0.72 . For beta-emitting radionuclides, the relationship was $\mathrm{Y}=(0.025) \mathrm{X}+$ 0.20 with a correlation coefficient of 0.87 .

The incidence rate was only moderately correlated with increased radiation dose. The incidence of other primary lung tumors, however, was markedly increased by increased dose to lung and was much greater than the mesothelioma incidence (Fig. 7).

The chronic alpha irradiation was more effective than the chronic beta irradiation in causing mesotheliomas. The risk of a malignant mesothelioma for various groups of rats was determined using the formula:

$$
\text { Tumors/Gy - } \frac{\text { number of mesotheliomas }}{\text { average dose } x \text { number in group }}
$$

Such a calculation assumes a linear dose response. Figure 6 illustrates that a linear dose response is reasonable in this situation. Using this approach, the risk of mesothelioma for alpha-emitting radionuclides deposited in the lung was 90 tumors $/ 10^{4} \mathrm{~Gy}$. For betaemitting radionuclides, it was 6 tumors $/ 10^{4} \mathrm{~Gy}$. The relative effectiveness ratio was:

$$
\frac{\text { Risk for } \alpha \text {-emitting radionuclides }}{\text { Risk for } \beta \text {-emitting radionuclides }}-\frac{90 \text { tumors } / 10^{4} G y}{6 \text { tumors } / 10^{4} G y}=15
$$

The results of these four studies of rats with radionuclides deposited in the lung show that pleural mesotheliomas can be induced with either inhaled alpha- or betaemitting radionuclides. Pulmonary fibrosis does not appear to be a prerequisite for these radiation-induced mesotheliomas as it appears to be for asbestos-induced mesotheliomas. The incidence of these tumors is dose dependent, but much less frequent than other radiation-induced lung tumors. Chronic alpha irradiation was more effective per unit 
dose in producing mesotheliomas than chronic beta irradiation of the lung by a factor of 15.

\section{ACKNOWLEDGMENTS}

Research supported $b$; the Office of Health and Environmental Research, U. S. Department of Energy, under Contract No. DE-AC04-76EV01013 and in facilities fully accredited by the American Association for Accreditation of Laboratory Animal Care.

\section{DISCLAIMER}

This report was prepared as an account of work sponsored by an agency of the United States Government. Neither the United States Government nor any agency thereof, nor any of their employees, makes any warranty, express or implied, or assumes any legal liability or responsibility for the accuracy, completeness, or usefulness of any information, apparatus, product, or process disclosed, or represents that its use would not infringe privately owned rights. Reference herein to any specific commercial product, process, or service by trade name, trademark, manufacturer, or otherwise does not necessarily constitute or imply its endorsement, recommendation, or favoring by the United States Government or any agency thereof. The views and opinions of authors expressed herein do not necessarily state or reflect those of the United States Government or any agency thereof. 


\section{REFERENCES}

Dagle, G.E., Sanders, C.L (1984) Radionuclide injury to the lung. Environ. Health Perspect. 55:129-137.

Lundgren, D.L., Haley, P.J., Hahn, F.F., Griffith, W.C., Seiler, F.A., Diel, J.H., McClellan, R.O. (1990) Pulmonary carcinogenicity of repeated inhalation exposure of rats to aerosols of ${ }^{239} \mathrm{PuO}_{2}$. In preparation.

Lundgren, D.L., Hahn, F.F., Griffith, W.C., Hubbs, A.F., Nikula, KJ., Newton, G.J., Cuddihy, R.C., Boecker, B.B. (1990) Carcinogenic effects of relatively low doses of beta-irradiation to the lungs from inhaled ${ }^{144} \mathrm{CeO}_{2}$ in rats. In preparation.

Mewhinney, J.A., Eidson, A.F., Hahn, F.F., Scott, B.R., Seiler, F.A., Boecker, B.B. (1987) Dose-response Study in F344 Rats Exposed to $(\mathrm{U}, \mathrm{Pu}) \mathrm{O}_{2}$ or $\mathrm{PuO}_{2}$, in Radiation Dose Estimates and Hazard Evaluation for Inhaled Airbome Radionuclides. Final Report to Office of Nuclear Regulatory Research, U. S. Nuclear Regulatory Commission, Washington, DC, NUREG/CR-4986, pp. 61-89.

Peterson, J.T., Greenberg, S.D., Buffer, P.A. (1984) Non-asbestos-related malignant mesothelioma - A review. Cancer 54:951-960.

Sanders, C.L, Jackson, T.A. (1972) Induction of mesotheliomas and sarcomas from "hot spots" of ${ }^{239} \mathrm{PuO}_{2}$ activity. Health Phys. 22:755-759.

Sanders, C.L (1973) Cocarcinogenesis of ${ }^{2} 3 \mathrm{PuO}_{2}$ with chrysotile asbestos or benzo[a]pyrene in the rat abdominal cavity, in Radionuclide Carcinogenesis (C.L Sanders, R.H. Busch, J.E. Ballou, and D.D. Mahlum, eds.), NTIS, Springfield, VA, CONF-720505, pp. 138-153. 


\section{Table 1}

Characteristics of Pleural Mesotheliomas in Rats

with Lung Burdens of ${ }^{144} \mathrm{CeO}_{2},{ }^{239} \mathrm{PuO}_{2}, \mathrm{PuO}_{2}$ or $(\mathrm{U}, \mathrm{Pu}) \mathrm{O}$

\begin{tabular}{lcccccc}
\hline & & \multicolumn{5}{c}{ Number of Mesotheliomas } \\
\cline { 3 - 7 } $\begin{array}{l}\text { Morphologic } \\
\text { Pattern }\end{array}$ & $\begin{array}{c}\text { Total } \\
\text { Number }\end{array}$ & Fatal & $\begin{array}{c}\text { Contributory } \\
\text { to Death }\end{array}$ & $\begin{array}{c}\text { Incidental } \\
\text { to Death }\end{array}$ & $\begin{array}{c}\text { With Focal } \\
\text { Fibrosis }\end{array}$ & $\begin{array}{c}\text { With Other } \\
\text { Lung Tumors }\end{array}$ \\
\hline $\begin{array}{l}\text { Epithelial, } \\
\text { Papillary, }\end{array}$ & 2 & 0 & 0 & 2 & 0 & 0 \\
$\begin{array}{l}\text { Focal } \\
\begin{array}{l}\text { Epithelial, } \\
\text { Papillary, }\end{array}\end{array}$ & 21 & 13 & 7 & 1 & 4 & 2 \\
$\begin{array}{l}\text { Diffuse } \\
\text { Sarcomatous }\end{array}$ & 2 & 1 & 1 & & & \\
Mixed & 3 & 2 & 1 & 0 & 1 & 2 \\
\hline
\end{tabular}

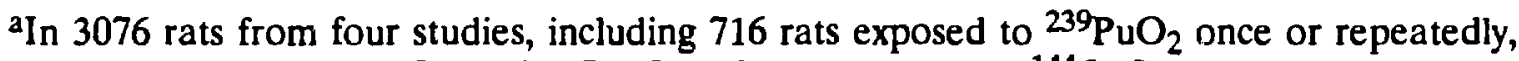
461 rats exposed to $\mathrm{PuO}_{2}$ or $(\mathrm{U}, \mathrm{Pu}) \mathrm{O}, 329$ rats exposed to ${ }^{144} \mathrm{CeO}_{2}$ once or repeatedly, and 1570 rats exposed to low doses of ${ }^{144} \mathrm{CeO}_{2}$. 


\section{FIGURE LEGENDS}

Figure 1. Retention patterns for radionuclides inhaled by F344 rats. a) ${ }^{239} \mathrm{PuO}_{2}$; b) $\mathrm{PuO}_{2}$ or $(\mathrm{U}, \mathrm{Pu}) \mathrm{O}_{2} ;$ c) ${ }^{144} \mathrm{CeO}_{2} ;$ d) ${ }^{144} \mathrm{CeO}_{2}$ low-dose exposure.

Figure 2. Exposure aerosol particles. a) Laboratory-produced monodisperse ${ }^{239} \mathrm{PuO}_{2}$ particles $-\mathrm{AMAD}=1.0 \mu \mathrm{m}, \sigma_{\mathrm{g}} 1.2$ b) Laboratory-produced polydisperse ${ }^{144} \mathrm{CeO}_{2}$ particles $-\mathrm{AMAD}=1.4 \mu \mathrm{m}, \mathrm{o}_{\mathrm{g}}$ 1.7. c) Mixed (U. $\left.\mathrm{Pu}\right) \mathrm{O}_{2}$ particles from fuel fabrication facility $-\mathrm{AMAD}=3.5 \mu \mathrm{m}, \sigma_{\mathrm{g}} 1.4$. Bar $=1 \mu \mathrm{m}$.

Figure 3. Mesothelioma, papillary epithelial pattern. $\mathrm{Bar}=100 \mu \mathrm{m}$.

Figure 4. Mesothelioma, sarcomatous pattern. Bar $=100 \mu \mathrm{m}$.

Figure 5. Mesothelioma, mixed pattern. Bar $=100 \mu \mathrm{m}$.

Figure 6. Dose response for mesothelioma after inhalation of alpha- or beta-emitting radionuclides. Mesothelioma incidence a linear function of dose according to the equation $Y=(0.95) X+0.029$ for alpha emitters (correlation coefficient $=0.72$ ) and $\mathrm{Y}=(0.025) \mathrm{X}+0.20$ for beta emitters (correlation coefficient $=0.87$ ).

Figure 7. Incidence of malignant mesotheliomas compared with incidence of other lung cancers in rats that inhaled a) alpha-emitting radionuclides or b) beta-emitting radionuclides. Control incidence $=4$ mesotheliomas $/ 1641$ rats $=0.24 \%$. 

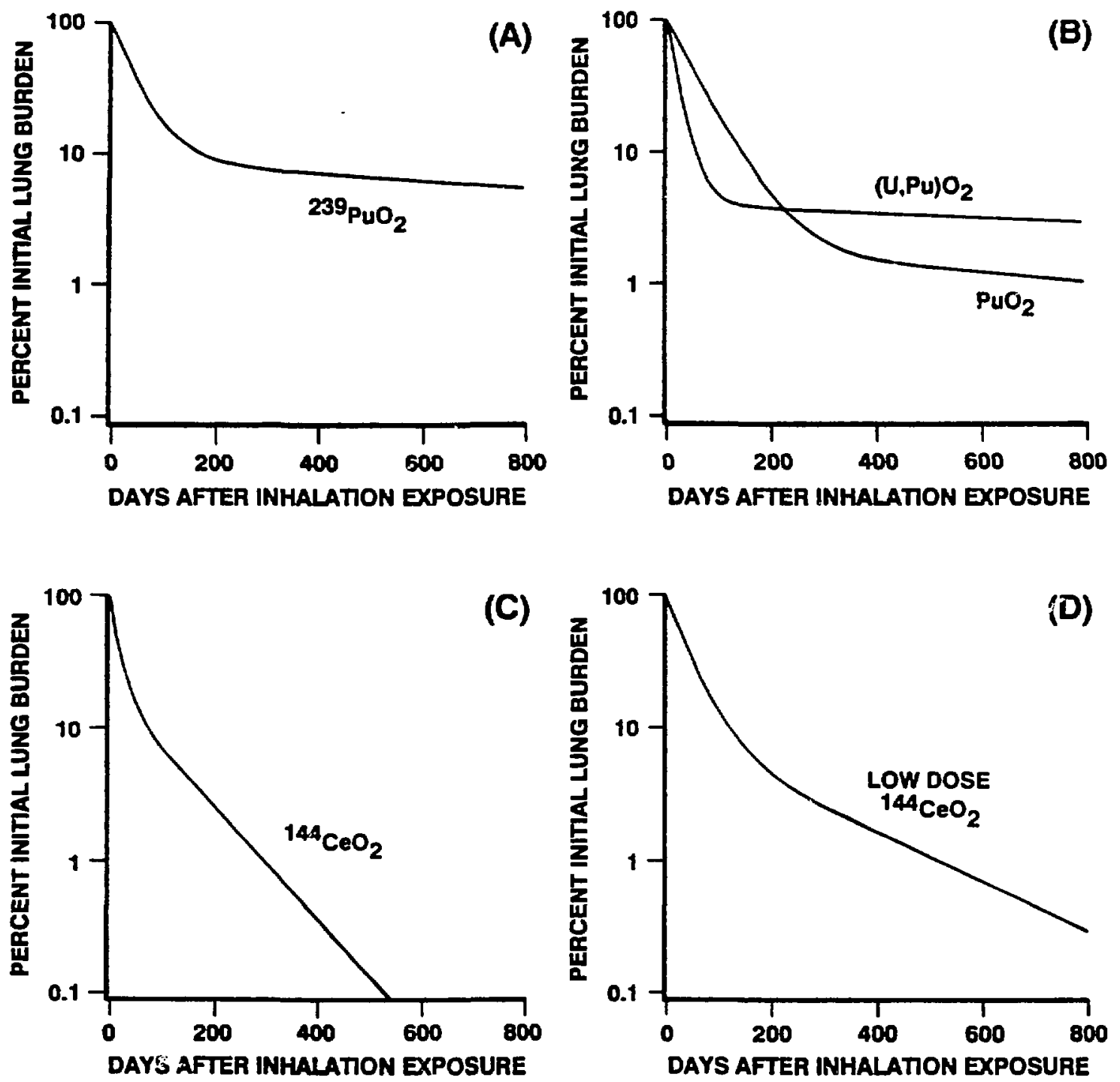
Firurez

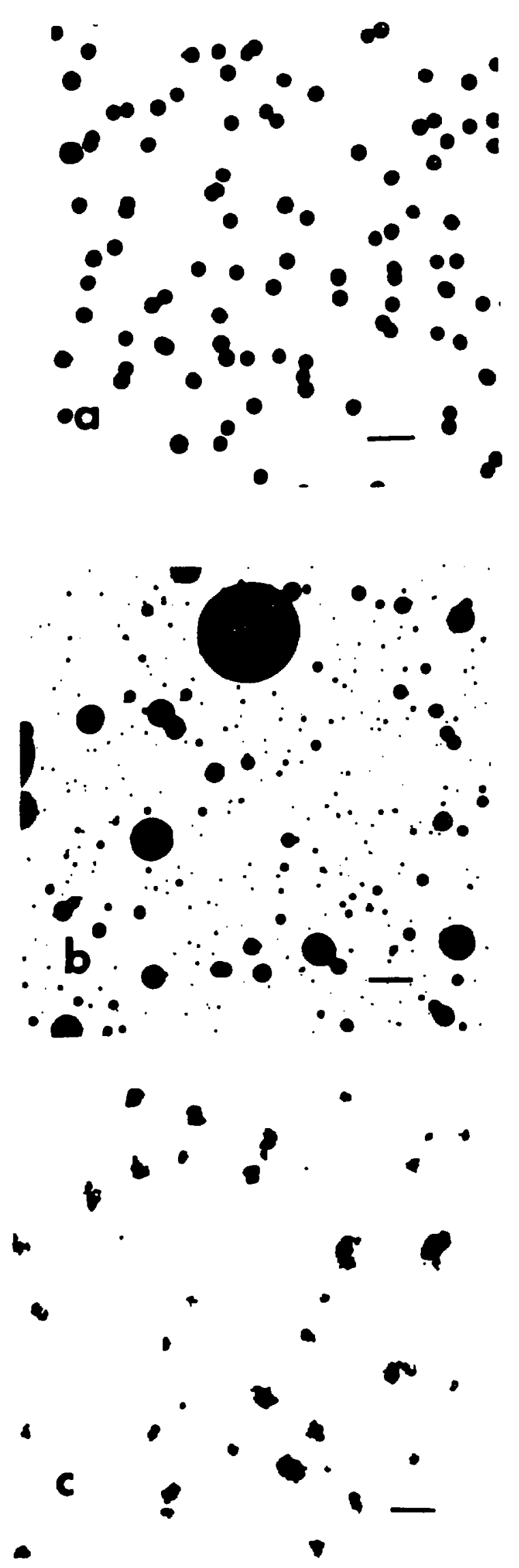



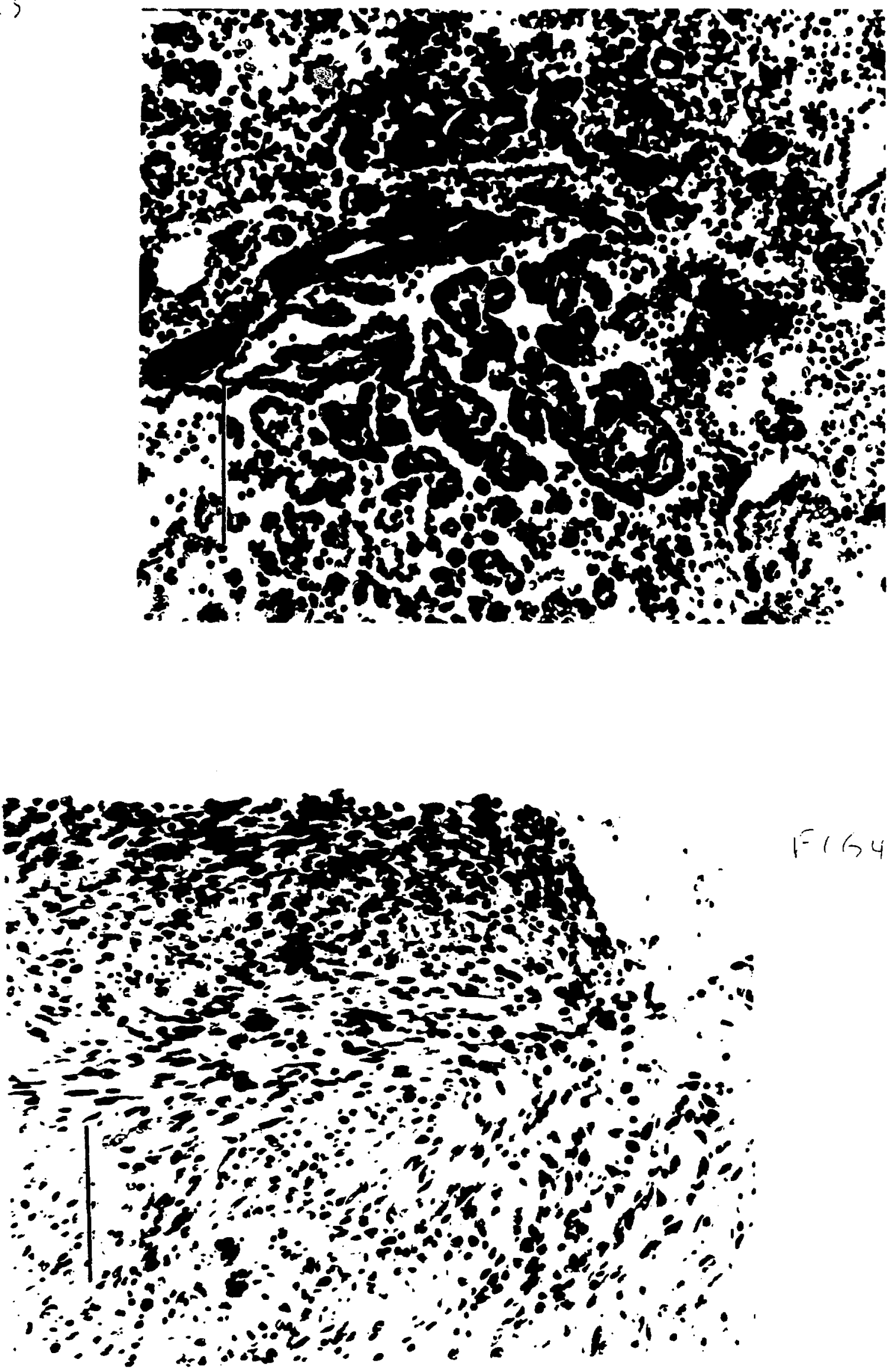


\section{Fics}

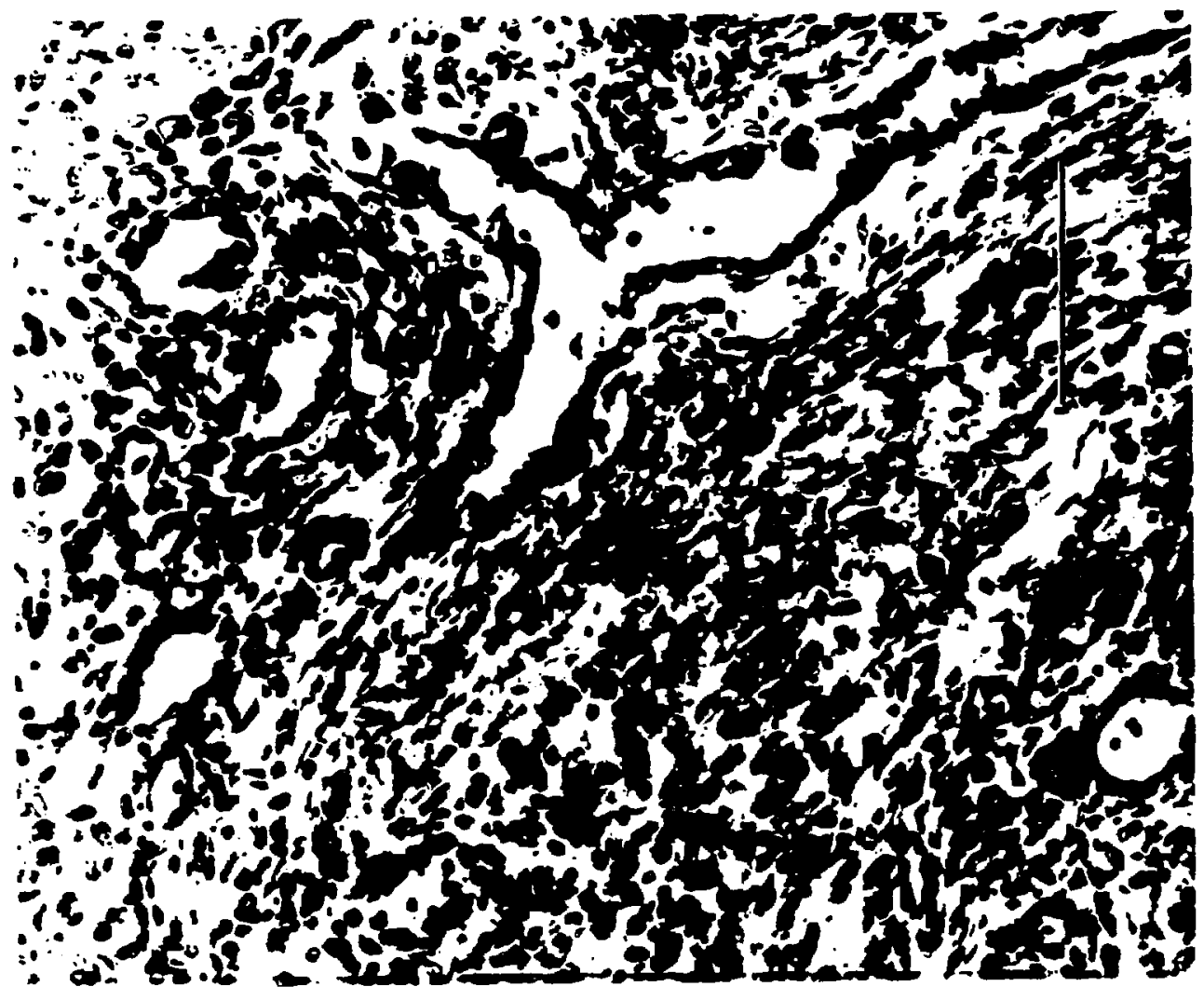




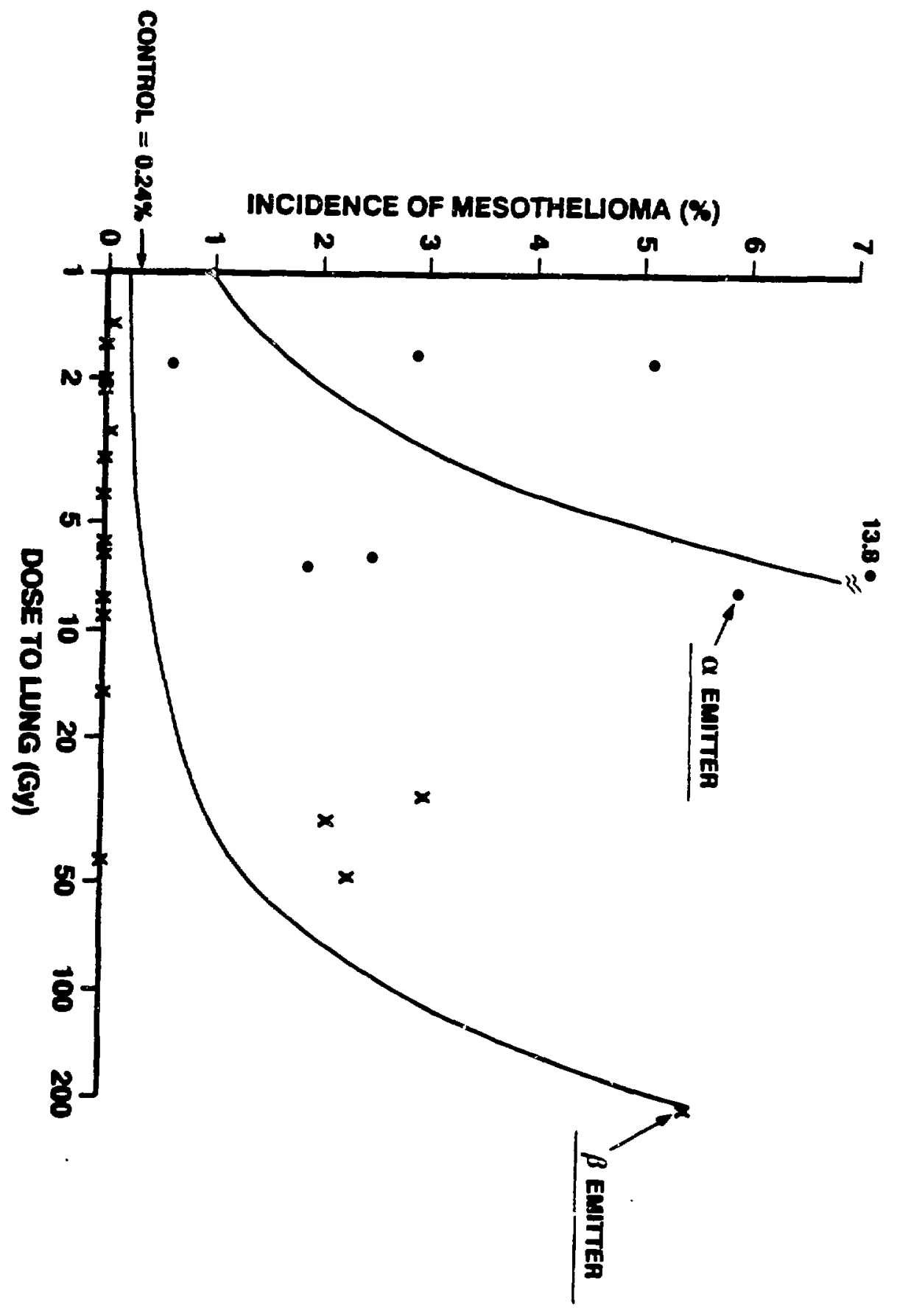

$\frac{1}{6}$

$E$ 

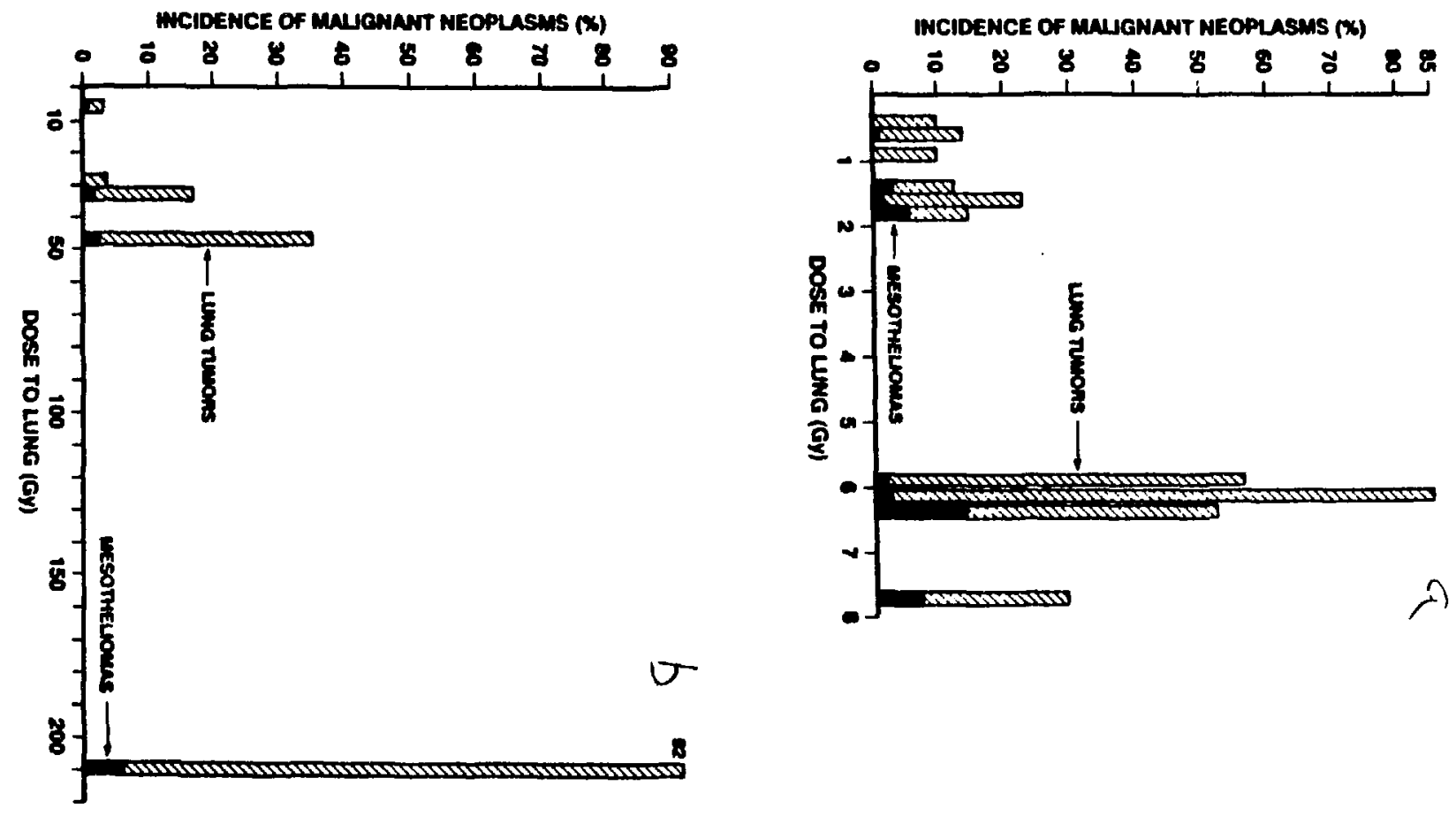

7
5
$c$
$r$
$r, 1$

$1]$ 